\title{
42. SUMMARY OF ACCRETIONARY PROCESSES, DEEP SEA DRILLING PROJECT LEG 66: OFFSCRAPING, UNDERPLATING, AND DEFORMATION OF THE SLOPE APRON ${ }^{1}$
}

\author{
J. Casey Moore, Earth Sciences, University of California, Santa Cruz, California \\ Joel S. Watkins, Gulf Science \& Technology Company, Pittsburgh, Pennsylvania \\ and \\ Thomas H. Shipley, Scripps Institute of Oceanography, University of California, San Diego, La Jolla, California
}

\begin{abstract}
Leg 66 results indicate that structural packages of trench sediment are scraped off at the toe of the trench slope and comprise a zone of landward-dipping reflectors increasing in age (Quaternary-Miocene) upslope. These reflectors are presumably bedding surfaces and their apparent stratigraphic inversion most simply explained by thrust faulting subparallel to bedding. The seismic reflection data suggest that offscraped, thrust-bound packages of trench sediment are about $1 \mathrm{~km}$ in structural thickness and up to $8 \mathrm{~km}$ in lateral extent down-dip. Imbricate wedging of these structural packages results in their modest landward tilt close to the base of the trench slope.

Landward of the zone of active offscraping and tilting the near uniform dip of the structural packages, coupled with their long-term uplift, suggests a subjacent process of mass addition or underplating beneath the external "rind" of older offscraped deposits. Trench deposits with possible additions of oceanic plate pelagic and hemipelagic deposits probably constitute the bulk of the underplated materials, a lithologic suite more diverse than the offscraped trench sediments. The lack of coherent reflections from the underplated terrane argues for complex deformation relative to the offscraped trench deposits. Depth of occurrence and thermal gradients predict a maximum of zeolite facies metamorphism for the offscraped deposits and zeolite to prehnite-pumpellite facies for the underplated deposits. Geologic contrasts between the offscraped and underplated terranes provide a basis for identifying possible ancient analogs in the Kodiak Islands of Alaska.

The rate of tilting of surface sediment decreases with distance from the base of the slope and with distance above the downgoing slab, indicating an extreme concentration of deformation at the base of the trench slope. Hence sediments accumulated on the lowermost slope are less likely to be structurally differentiable from the underlying offscraped rocks than those deposited farther upslope.
\end{abstract}

\section{INTRODUCTION}

Although few would doubt that material is actually accreted at convergent margins, much remains to be learned about the tectonic processes involved. Topics requiring further study include (1) the overall structure of the accretionary zone and the processes of mass addition accompanying its growth; (2) the type of strain, and the distribution of total strain and strain rates, throughout the accretionary zone; and (3) the processes and conditions under which the distinctive structural styles of accretionary complexes develop. These problems and others can be approached by the analysis of ancient subduction complexes on land (e.g., Cowan, 1978; Moore and Karig, 1980; Byrne, 1981; Moore and Wheeler, 1978), by physical (Cowan and Silling, 1978; Seely, 1977) and numerical modeling (Cloos, in press), and by analysis of active subduction complexes in the modern marine environment (e.g., Seely et al., 1974; Seely, 1977; Karig et al., in press; von Huene et al., 1980; Carson et al., 1974; Silver, 1972; Moore et al., 1979; Moore and Karig, 1976).

Herein we focus on problems of structural evolution of accretionary complexes as elucidated by the results of Leg 66 . Specifically we present information on (1) the stratigraphic evidence and potential for resolution of

\footnotetext{
${ }^{1}$ Initial Reports of the Deep Sea Drilling Project, Volume 66.
}

thrusting; (2) the geometry of offscraped thrust-bound sediment packages; (3) the evidence for, nature of, and kinematics of underplating occurring beneath the offscraped trench deposits; and (4) the propagation of deformation through the slope apron.

This chapter focuses on the processes of mass addition or accretion which have no standardized terminology. As such, we use "accretionary terrane" to refer to all material that is structurally transferred from the lower to the upper plate during crustal convergence. "Offscraping" describes accretion (principally of trench sediments) at the base of the trench slope. "Underplating" designates a process of mass addition at depth beneath the rind of offscraped deposits. In our usage the term accretion refers to mass addition in general, whereas offscraping and underplating indicate a particular tectonic process. An accretionary terrane by definition excludes slope deposits accumulated in situ. In practice, however, it may be very difficult to distinguish accreted rocks from highly deformed slope deposits.

\section{TECTONIC SETTING}

The Pacific margin of southern Mexico is characterized by a rugged coastal mountain range, a narrow continental shelf, and a steep trench slope that lacks a forearc basin (Fig. 1). The Middle America Trench in the Leg 66 area is about $5 \mathrm{~km}$ deep and marked by a series of discontinuous sediment ponds with a maximum of 625 meters of turbidite fill overlying about 200 meters 


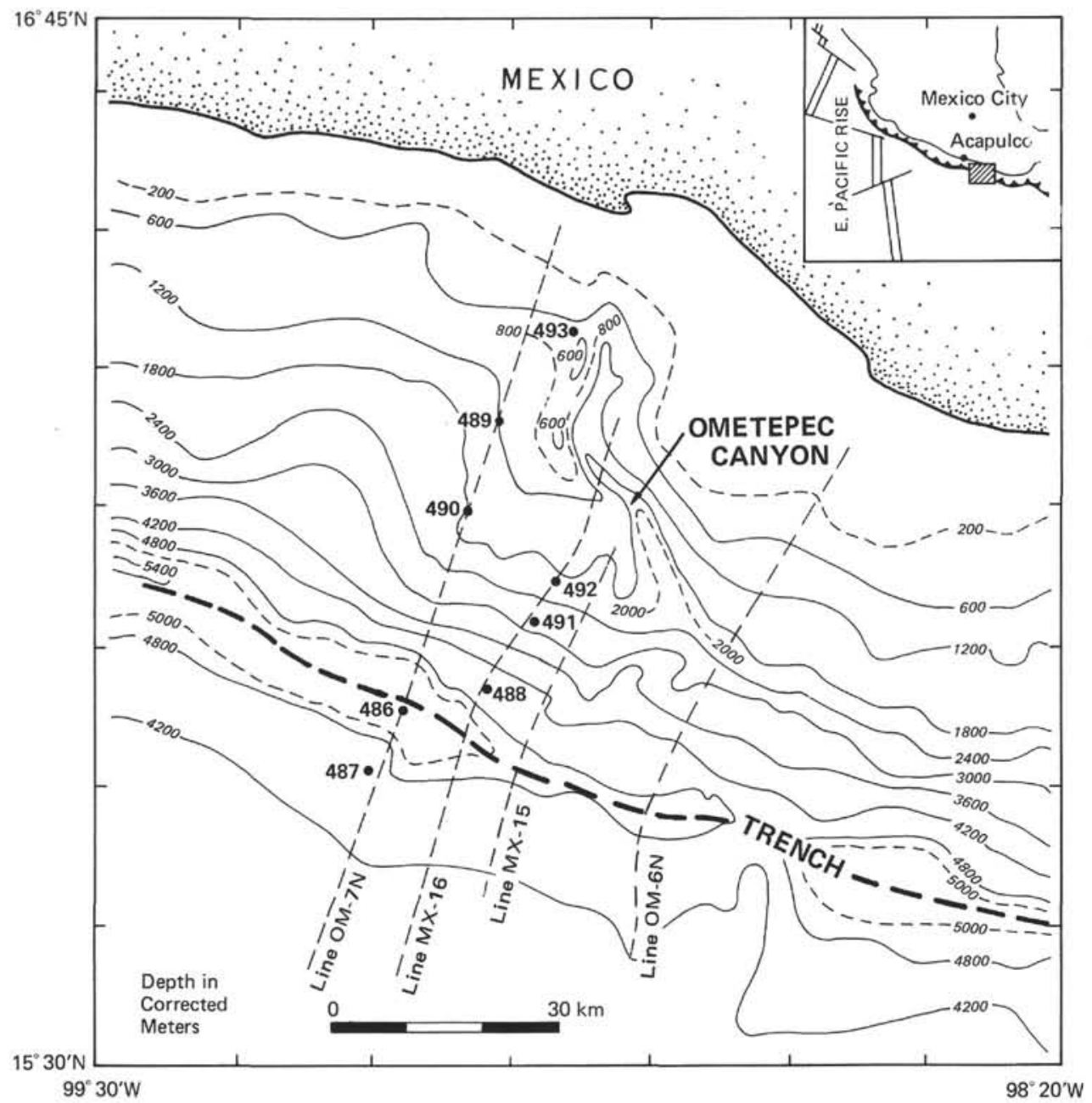

Figure 1. Bathymetry (Shipley et al., 1980) and location of seismic lines OM-7N, MX-16, MX-15, and OM-7N.

of pelagic and hemipelagic sediment which rests on Miocene oceanic crust (Fig. 2). In the Leg 66 drilling area the Cocos Plate converges beneath the North American Plate at about $7 \mathrm{~cm} / \mathrm{y}$. along an azimuth of $038^{\circ}$, an orientation of about $20^{\circ}$ from perpendicular to the trench (Minster and Jordan, 1978).

Plate tectonic reconstructions and the magmatic history of the continental margin both suggest that con- vergence has been occurring at least intermittently beneath southern Mexico for about 100 m.y. (Karig, et al., 1978). Although an extensive accretionary terrane covered by a substantial slope apron would be expected along this margin in view of its long history of subduction, Mesozoic and Paleogene intrusions and associated basement rocks (Mejorada, 1976) occur at the shoreline and are shown, by magnetic, seismic, and drilling data,

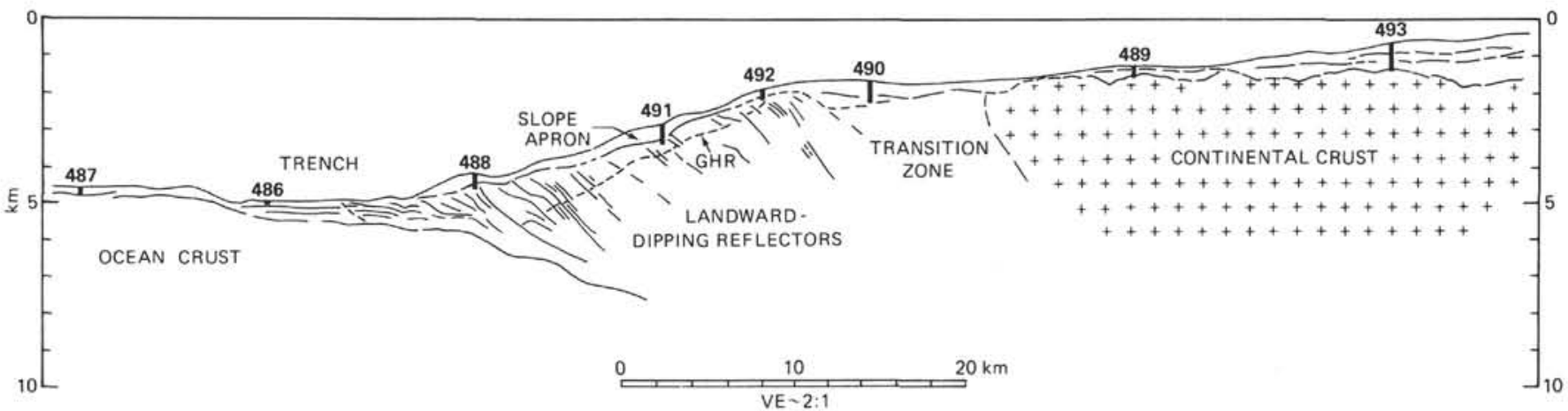

Figure 2. Generalized cross section along Leg 66 transect. Portion from Site 490 landward and 486 seaward taken along seismic line OM-7N; remainder along seismic line MX-16. GHR indicates gas hydrate reflector. 
to extend $35 \mathrm{~km}$ from the trench (Karig et al., 1978; Shipley et al., 1980). Neogene rocks both overlie the basement and are faulted against its seaward boundary, suggesting removal of any pre-existing Mesozoic and/or Paleogene forearc and accretionary terrane. The present phase of accretion apparently commenced in the Neogene (Moore et al., 1979) and was coupled with magmatism in the Trans-Mexican volcanic belt (Cantagrel and Robin, 1979).

Along the Leg 66 transect, geophysical and drilling data define basement characterized by landward-dipping reflectors $25 \mathrm{~km}$ wide separated by a narrow transition zone from continental crust (Fig. 2). The zone of landward-dipping reflectors probably represents accreted trench deposits (Moore et al., 1979, and Chapters 4,7 , and 8 , this volume). The mass of accreted deep sea deposits in the Leg 66 area is small and young and probably represents a relatively early stage in the development of a broad zone of accretion such as that occurring in the Barbados area (Westbrook, 1975) of the Lesser Antilles or the Kodiak area of southern Alaska (von Huene et al., 1979). As such, the convergent margin in the Leg 66 area off southern Mexico represents but one in a range of tectonic styles in this setting (Scholl et al., 1980). Subduction zones with a tectonic style similar to that of southern Mexico may have occurred along western North America during the Mesozoic; the Cretaceous subduction zone bordering the Salinian block in California may be an example (Page, 1981).

\section{OFFSCRAPING}

\section{Regional Evidence for Offscraping}

The seaward decrease in age of the landward-dipping reflectors constitutes one of the most fundamental results of Leg 66 (Fig. 3 and Chapters 4, 7, and 8, this volume). This systematic age progression indicates seaward growth of the continental margin irrespective of how the dipping reflectors are interpreted. In considering the origin of these landward-dipping reflectors, crucial unknowns are the depositional environment of the sediments comprising the reflectors and the nature of the surfaces causing the reflections. The interbedded massive sand and mudstone cored in the zone of landward-dipping reflections probably represent trench deposits, judging from comparisons with distribution of the modern sediment in the Leg 66 area (see detailed arguments for trench rather than slope basin deposition in Moore et al., 1979, and Chapters 4, 7, and 8, this volume). The landward-dipping reflectors also are acoustically similar to and can be traced from modern slightly deformed trench deposits (Figs. 4-6), providing further support for their deposition in this environment. The reflections probably are caused by contrasts in density and velocity between the mudstone and thick, unconsolidated sand beds cored in the zone of landwarddipping reflectors. Paleomagnetically oriented bedding planes in mudstone from the zone of landward-dipping reflectors tend to dip northeasterly, supporting the contention that these surfaces actually generate the observed reflections (Niitsuma, this volume). If the land-

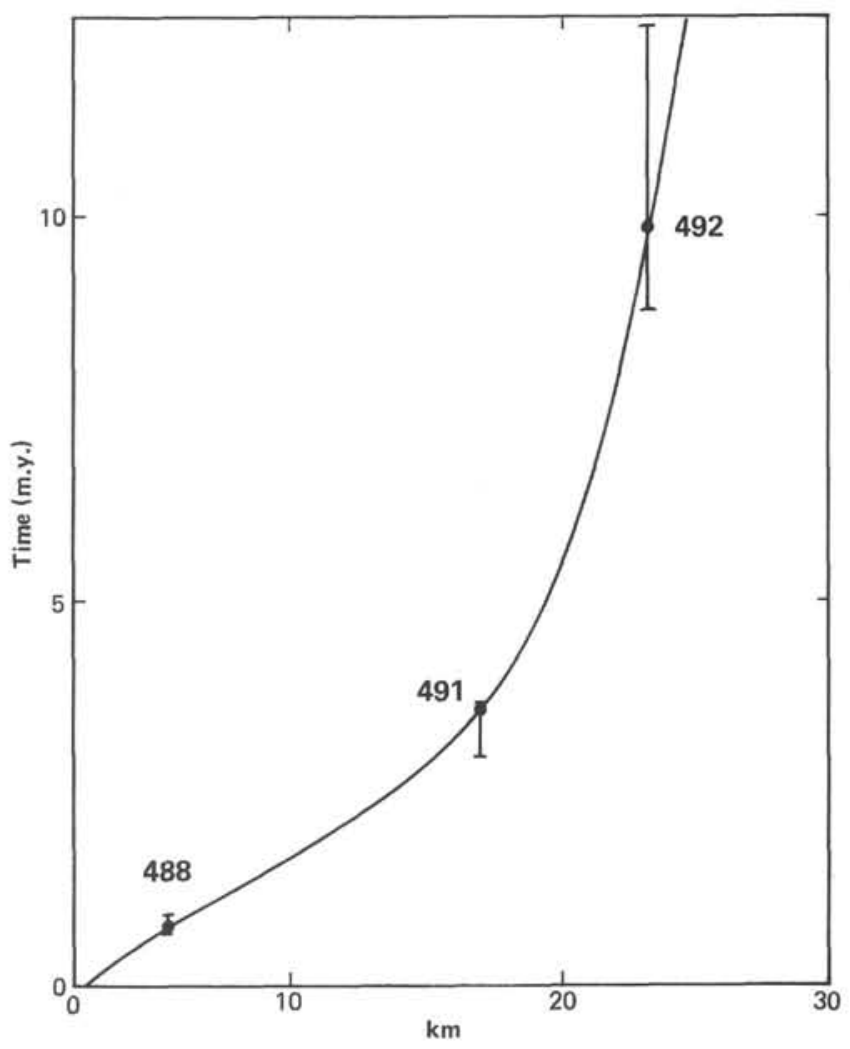

Figure 3. Age of zone of dipping reflectors versus distance from the base of the trench slope. Error bars represent biostratigraphic zone at upper surface of zone of tilted reflectors encountered in drill holes.

ward-dipping reflectors are bedding surfaces and increase in age upslope, they violate the law of superposition and require a structural interpretation. Single or multiple thrust faults between each of the drill sites provide the simplest explanation of the age relationships.

Although the age of the dipping reflectors generally increases landward, the rate of increase is greatest between Sites 491 and 492 (Fig. 3). Hence the rate of seaward accretion of the continental margin was faster from the present to about $3 \mathrm{Ma}$ than from 3 to $10 \mathrm{Ma}$. The sedimentation rates in rocks older than $3 \mathrm{Ma}$ at Site 492 are significantly lower than in comparable facies at Sites 488 and 492 (Shepard and McMillen, this volume). As such, the lower accretion rate between Sites 491 and 492 may simply reflect a lesser volume of material supplied to the continental margin. Alternatively, it may imply progressive structural modification resulting in a component of shortening perpendicular to the continental margin. Other explanations are also possible.

\section{Resolution of Thrust Faults in Drill Holes}

On Leg 66 we failed to resolve stratigraphically a thrust fault in a single drill hole, even though Site 488 was located a few hundred meters landward of the surface expression of a fault of presumed thrust origin (Chapter 4 , this volume). At Site 488 we discovered no stratigraphic or geotechnical evidence of faulting at a depth of 80 to $150 \mathrm{~m}$ where the thrust fault would apparently transect the drilled section (Chapter 4, this vol- 

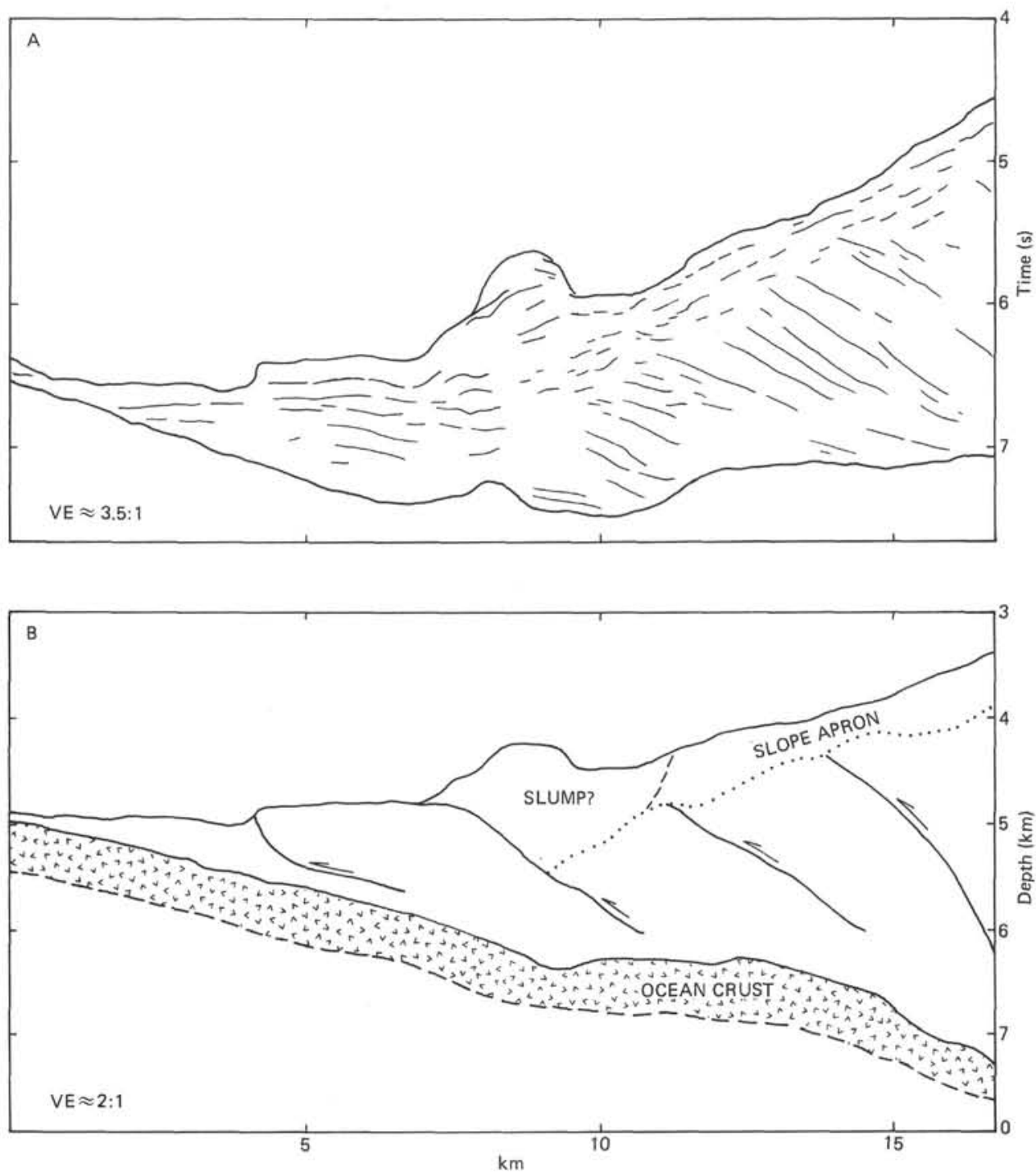

Figure 4. A. Line drawing of migrated time section MX-15 (Shipley, this volume; VE $=\sim 3.5: 1$ ). B. Interpretation and depth conversion of line drawing emphasizing position of major faults ( $\mathrm{VE}=\sim 2: 1$ ). Gas hydrate reflector omitted.

ume). Conversely, structural fabrics and anomalously low porosity suggests that a fault zone occurs from 200 to 240 meters sub-bottom at Site 488 , even though we find no seismic evidence for faulting at this depth (Chapter 4, this volume; Lundberg and Moore, this volume; Shepard, this volume). These ambiguities between seismic and drilling data require a critical examination of stratigraphic evidence for the recognition of faults in a single drill hole.

Crucial factors limiting the stratigraphic documentation of faults on the lowermost slope include high sedimentation rates, poor fossil assemblages, and faulting at low angles relative to bedding. Since the trench and lowermost slope sediments almost invariably accumulate below the CCD, key fossil types may be absent, reducing biostratigraphic resolution. High sedimentation rates and the consequent dilution of fossil materials may also impede biostratigraphic resolution. In addition to dilution effects, high sedimentation rates also hinder the recognition of faults by distributing a given biostratigraphic zone through a section thicker than that accumulating at a lower sedimentation rate. Similarly, faults cutting bedding at a low angle require large displacements in order to generate an age inversion.

High sedimentation rates, poor biostratigraphic resolution, and low-angle faulting, factors that impede recognition of faults in single drill holes, are best summarized by the following illustration. The average biostratigraphic resolution at Sites 488,491 , and 492 is about $1 \mathrm{~m} . y$. At sedimentation rates occurring on the lower slope and in the trench (see site chapters), the average biostratigraphic zone (1 m.y.) would be distributed through a sediment pile 360 to 2600 meters thick. For a thrust fault cutting bedding at $20^{\circ}$, the minimum displacement required to cause a stratigraphic inversion would be from 1 to $7.6 \mathrm{~km}$, depending on the sedimentation rate. Greater displacements would be required for faults cutting bedding at even lower angles. Apparently 

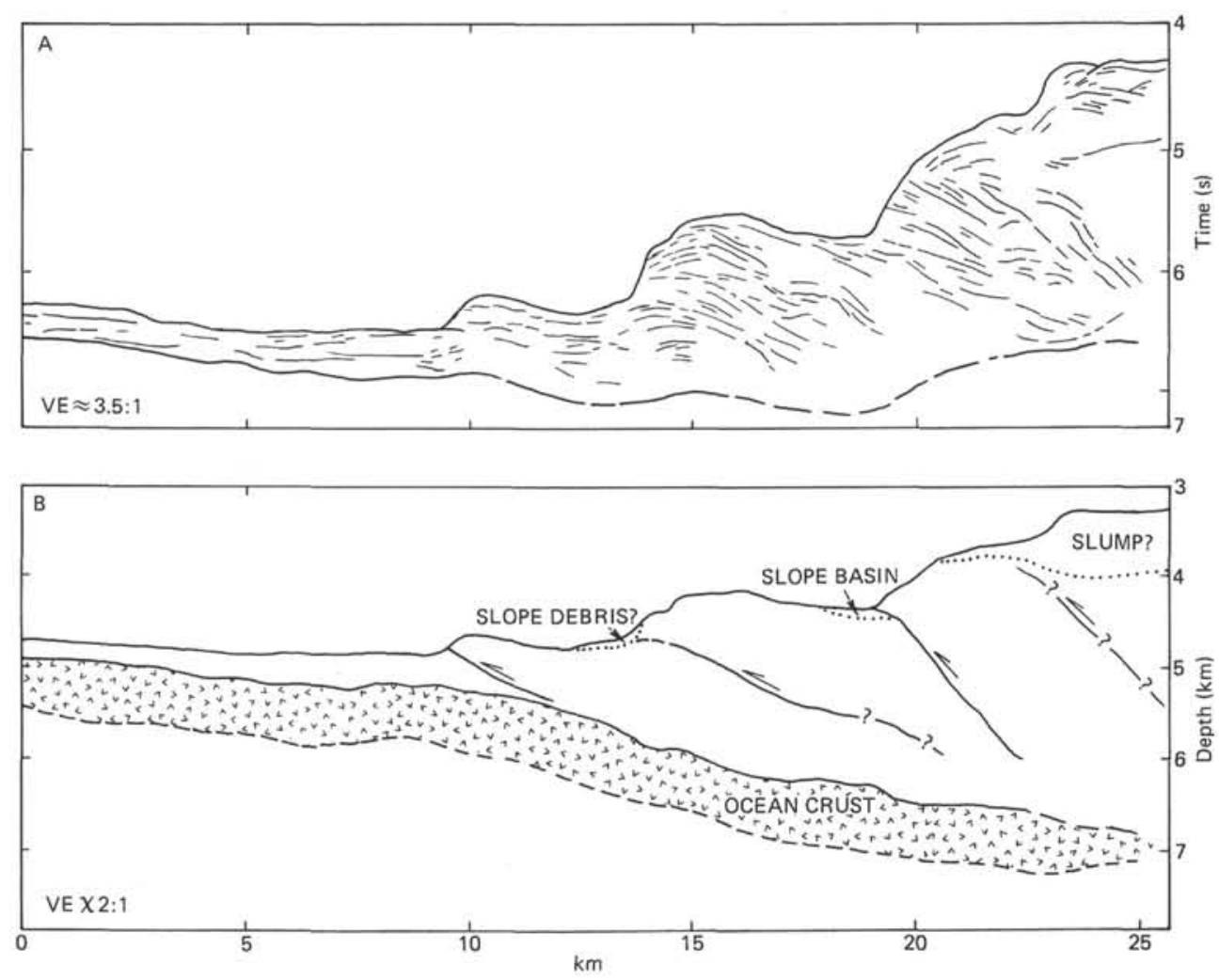

Figure 5. A. Line drawing of migrated time section OM-6N (Shipley et al., 1980; VE $=-3.5: 1$ ). B. Interpretation and depth conversion of line drawing showing position of major faults and surficial features $(\mathrm{VE}=\sim 2: 1)$.

none of our drill holes on the lower slope penetrated a fault of sufficient displacement to be resolved stratigraphically.

\section{Geometry of the Structural Package Presently Being Offscraped}

Although the drilling data argues for progressive offscraping of trench deposits in the Leg 66 area, significant questions remain regarding the geometry and temporal evolution of the offscraped packages. In the subsequent three sections of this chapter we define the geometry of the sediment package presently being offscraped, delineate and geometrically describe older structural packages upslope along the Leg 66 drilling transect, and interpret the progressive structural evolution of the offscraped deposits. The essential information supporting our discussion is derived from line drawings of seismic reflection data and interpretations published elsewhere (Shipley, this volume; Shipley et al., 1980).

To clarify the offscraping process we have made line drawings and depth sections along seismic lines OM-6N, $\mathrm{MX}-15$, and MX-16 which intersect the trench in an area of high sediment supply adjacent to the Leg 66 transect (Figs. 1, 4-6). All three seismic lines show a large discrete package of trench sediments being emplaced beneath the inner slope. On seismic line MX-15 the landward half of the trench fill is uplifted about 100 meters above its undeformed seaward half, presumably because of a landward-dipping thrust fault (Fig. 4, 4-7 $\mathrm{km})$. Similarly, on seismic line OM-6N the first terrace landward of the undeformed trench fill rises abruptly, apparently along a thrust fault (Fig. 5). The landward half of the trench fill on seismic line MX-16 is characterized by low-amplitude folds which are underlain and bounded on their seaward margin by a fault (Fig. 6). Note that ocean crust is not faulted beneath the uplifted or folded trench sediments along the aforementioned seismic lines, requiring that the proposed thrust faults root in the sedimentary section above the basement. The geometric similarity of the cross sections of the sediment package presently being offscraped (Fig. 7) argues for its continuity between seismic lines MX-16, MX-15, and OM-6N. Moreover, detailed bathymetric (Seabeam) data in this area indicate that both the seaward and landward boundaries of the deformed trench fill lie along continuous scarps, presumably thrust faults (Renard et al., 1980). The structural package presently being offscraped ranges from 600 to 800 meters thick with a sharp deformation front defining its seaward limit. The package can be traced landward for up to $8 \mathrm{~km}$, where the reflectors lose definition (Fig. 7).

\section{Structural Packages Upslope along the Leg 66 Transect}

In addition to the structural package presently being emplaced, seismic reflection data define similar but older packages landward of the base of the trench slope along the Leg 66 transect. Variously processed displays of seismic line MX-16 tend to show groups of landwarddipping reflectors separated by zones largely free of reflections. We preferentially interpret the groups of re- 

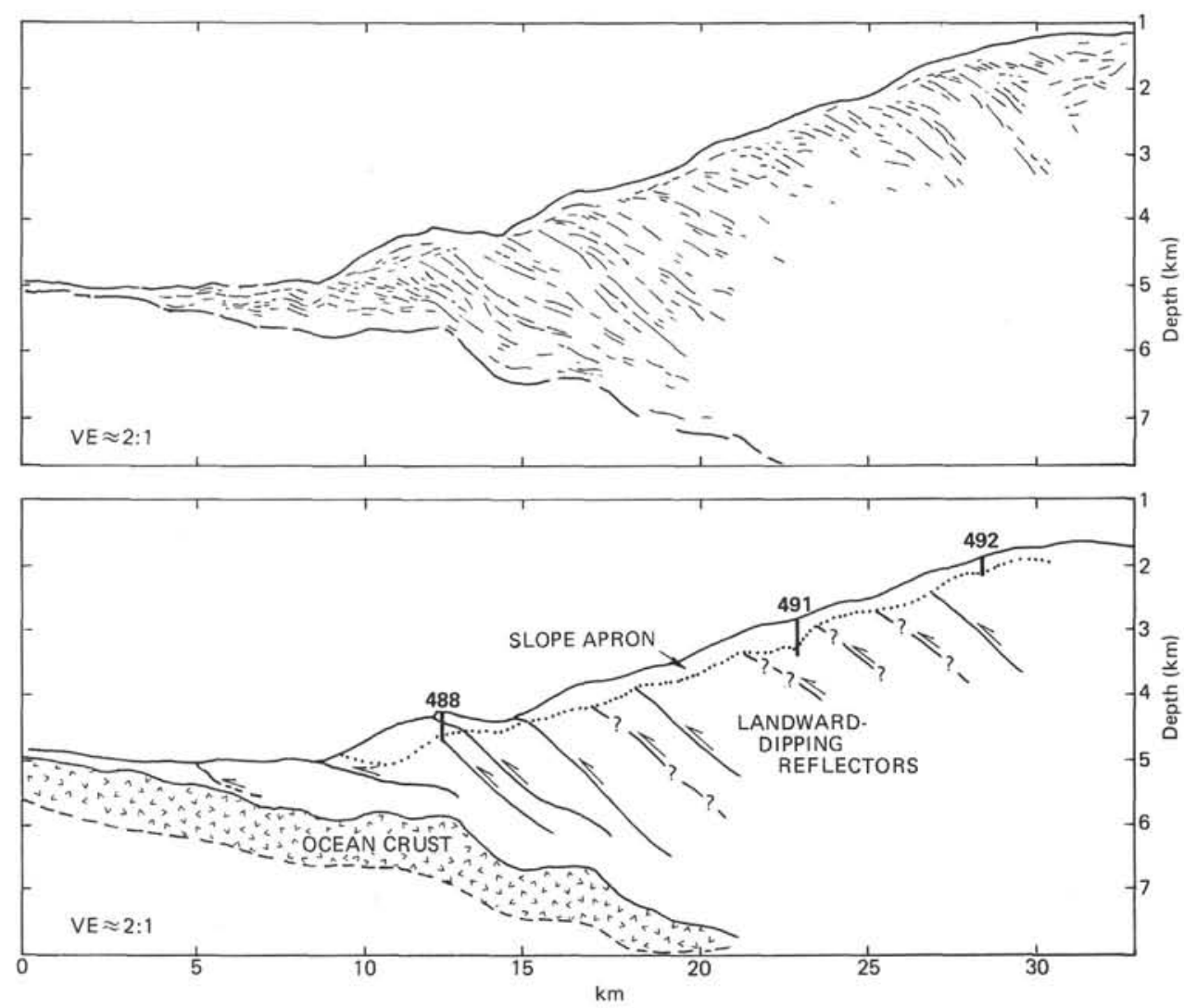

Figure 6. A. Line drawing of migrated depth section MX-16 (Shipley, this volume). B. Interpretation of line drawing showing position of major faults, surficial features, and Leg 66 drilling localities. Gas hydrate reflector omitted. $\mathrm{VE}=\approx 2: 1$.

flections as less-deformed structural packages and the bounding reflection-free zones as faults with associated zones of complex small-scale deformation that diffuse seismic energy. Alternatively, the reflection-free zones might represent bedded sequences lacking density and velocity contrasts. Groups of landward-dipping reflections also may show small angular discordances which we interpret as faults. Application of these two interpretive guidelines to seismic line MX-16 defines 10 older structural packages with an average thickness of 1.2 $\mathrm{km}$. The resolvable down-dip extent of these packages ranges up to $8 \mathrm{~km}$, although no individual reflections extend more than $5 \mathrm{~km}$. As interpreted from the reflection profiles, the older packages are thicker and on the average shorter than the structural package now being accreted at the base of the slope. The greater thickness and shorter down-dip of the older structural packages may be due to progressive structural thickening and shortening. Alternatively, we may have overestimated the average thickness of the older packages by failing to recognize faults, and the shorter lateral extent may be due simply to lack of resolution of the dipping reflections at depth.

Inspection of seismic line MX-16 (Fig. 6) as well as all seismic lines elsewhere in the Leg 66 area demonstrates that the dipping reflectors are shallowly inclined near the base of the slope but steepen to about $25^{\circ}$ within 8 $\mathrm{km}$ landward of its base (Shipley, this volume; Shipley et al., 1980). Following initial tilting, the reflections do not systematically steepen in a landward direction. Although the dipping reflections apparently represent bedding planes, it is noteworthy that faults bounding the structural packages are subparallel to bedding and show a similar symmetry. Moreover, the seismic data do not exclude the possibility that some of the reflections are faults.

\section{The Slope Apron and Slump Deposits}

The landward-dipping reflectors terminate up-dip against discontinuous and generally slope-parallel reflectors which comprise the slope apron. Drill cores and piston cores indicate this seismically defined slope apron is mud-dominated and apparently was deposited in situ (Chapters 4, 5, 7, 8, this volume; McMillen and Haines, this volume). Locally the slope apron thickens abruptly (Fig. 4 at $9 \mathrm{~km}$ and Fig. 6 at $12 \mathrm{~km}$ ). These thicker accumulations show discontinuous internal reflectors, clearly are not ponded sediment, and have not been deposited in layer-by-layer continuity with the remainder of the slope deposits. Rather, the abruptly thickened portions of the slope apron probably represent slump deposits derived from the collapse of steep scarps developed from and continually oversteepened by thrust faulting.

\section{Evolution of Offscraped Structural Packages}

The foregoing sections of this paper provide a data base for modeling the tectonic evolution of zone of 


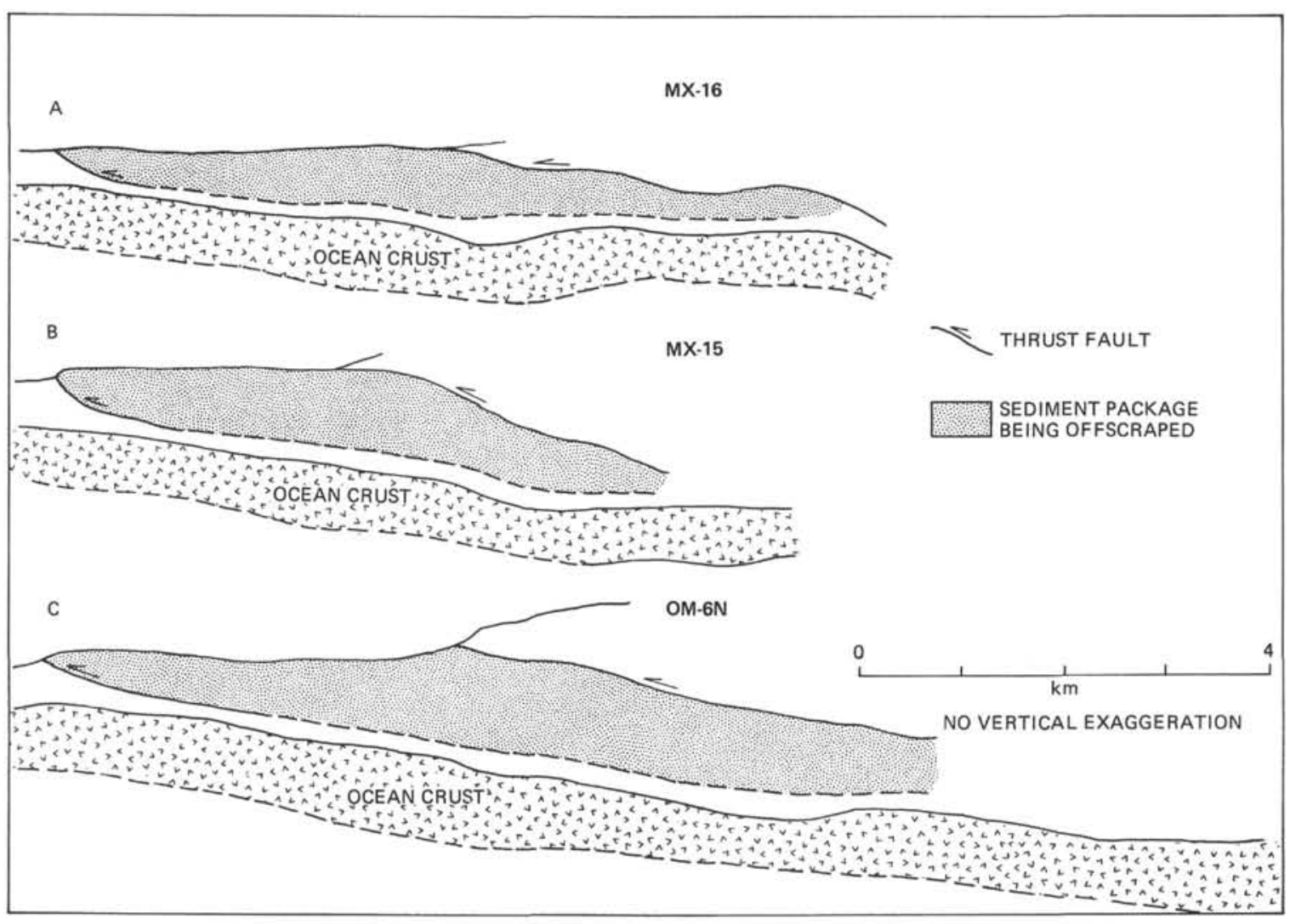

Figure 7. True-scale cross sections showing sediment package currently being of fscraped along seismic lines MX-16 (A), MX-15 (B), and OM-6N (C). Sections A to C sequentially span trench from northwest to southeast, respectively. VE $=1: 1$.

landward-dipping reflectors. The geometry of the structural package currently being underthrust constitutes the key to unlocking this structural puzzle.

When displayed at true scale (Fig. 7) the structural package currently being offscraped resembles a distorted parallelogram, with the slope of the opposed faces being of unequal magnitude. Underthrusting of the landward termination of the parallelogram results in tilting of the pre-existing structural package (Seely et al., 1974; Karig, 1974). Along seismic line MX-16 the entire tilting process is completed near the base of the trench slope by imbrication of the tapering landward terminations of several structural packages and by flexure of the underthrust ocean crust. Flexure of the ocean crust accounts for a maximum of $10^{\circ}$ of tilt, whereas the imbricate wedging process produces an additional $15^{\circ}$ tilt. The underthrusting and tilting of the trench deposits probably account for the rapid uplift of Site 488 (McMillen and Bachman, this volume). The imbricate wedging process is now restricted near the toe of the trench slope and probably functioned in a similar relative position during the previous $10 \mathrm{~m} . \mathrm{y}$. of accretion. Thus imbricate wedging as it operates off southern Mexico contrasts sharply to the continuous tilting process that is presumed to produce steeply dipping thrust faults (e.g., Karig, 1974; Seely et al., 1974; Moore and Karig, 1976). The vertically dipping bedding planes and foliations in some ancient accretionary complexes (e.g., Byrne, in press; Moore and Wheeler, 1978; Moore and Karig, 1980; Suppe, 1973, Duffield and Sharp, 1975) cannot be produced by imbricate wedging as displayed in the Leg 66 area and must be explained by an alternate or subsequent tectonic process.

During offscraping, the seaward wedge-shaped termination of the structural packages rides over the adjacent seafloor forming a scarp, locally draping into a series of seaward-dipping reflectors (Fig. 5). The scarp or draped mass formed by this overthrusting process has generated probable slumps and debris flows (Figs. 4-6). Similarly, in the Nankai Trough (Moore and Karig, 1976) and in the Sunda Trench (Karig et al., 1980) tectonic scarps formed during accretion are the presumed source of debris flows.

\section{UNDERPLATING}

\section{Evidence for Underplating}

The seismic reflection data in the Leg 66 area indicate that the package of trench sediment presently being accreted, as well as older packages, are limited to about 8 $\mathrm{km}$ in down-dip (Figs. 4-7; Shipley et al., 1980; Shipley, this volume). Clearly these seismic packages are emplaced near the base of the slope with the imbricate wedging (see the foregoing) accounting for their initial rapid uplift and landward tilting. Landward of this accretionary zone at the base of the trench slope, uplift occurs at a reduced by approximately constant rate (McMillen and Bachman, this volume). The overall uplift geometry of the trench slope and the limited down-dip of the accretionary packages require that they 
form an external rind to the entire accretionary zone (Fig. 8; Watkins et al., in press; Watkins et al., this volume). An underplating or mass addition process occurring landward to the down-dip extent of the accreted sediment packages is necessary to explain the uplift of the trench slope landward of its tectonically active toe (Watkins et al., in press; Watkins et al., this volume). Uplift of the trench slope cannot be explained simply by the decreasing age and hence elevation of the ocean crust being underthrust (Watkins et al., this volume). Because the uplift rates of the landward portion of the accretionary terrane, the transition zone, and the continental crust are comparable, underplating presumably operates in a similar manner beneath these three regions (Watkins et al., in press; Watkins et al., this volume). The requirement for underplating the trench slope is in accord with clay model experiments of Cowan and Silling (1978) which show that only part of the underthrust sediment pile is scaped off the descending plate with the remainder underplating and flowing upward beneath the accretionary zone.

\section{Characteristics of Underplated as Compared to Offscraped Deposits}

The following attempt to predict the characteristics of underplated deposits is based on (1) the types of material entering the subduction and hence available for underplating; (2) the seismic character of the underplated zone; and (3) thermal gradients. The nature of the offscraped deposits is known from direct sampling.

Mass balance calculations (Watkins et al., this volume) suggest that the underplated rocks should be principally composed of trench sediments. Yet the seismic reflection data (Figs. 4-7; Shipley, this volume) indicate that thrusts bounding the offscraped sediment packages commonly root in the pelagic and hemipelagic sediments. This structural geometry suggests offscraping of the bulk of the trench deposits at the base of the slope, with only hemipelagic and pelagic sediments remaining for underplating and sediment subduction. The seem- ingly contradictory evidence from the mass balance and seismic reflection studies might be reconciled by a longer-term view. Possibly some of the parameters controlling the mass balance calculations are inadequately measured in the modern environment. Moreover, thrust faults have not always rooted in the hemipelagic and/or pelagic sediments, allowing for the deeper underthrusting of trench sediments during the previous history of this subduction zone. We conclude that the underplated zone probably includes trench and hemipelagic and pelagic deposits of the lower plate. The underplated terrane would be more argillaceous than the offscraped terrane to the degree that the former includes hemipelagic or pelagic deposits.

The lack of coherent reflectors from the zone of underplating may be due to (1) uniform material lacking impedance (density and velocity) contrasts; (2) very high acoustic absorption causing a lack of acoustic returns; and (3) extremely complex deformation causing a chaotic reflection pattern. It is unlikely that any underplated trench sediment would be physically more uniform than that comprising the zone of dipping reflectors. Moreover, any admixture of hemipelagic or pelagic sediment would contribute to the lithologic heterogeneity and therefore to impedance contrasts within the underplated zone. A lack of acoustic returns from the underplated zone seems implausible since it lies within 2 $\mathrm{km}$ of the bottom near Site 492 and since coherent reflections occur 3 to $4 \mathrm{~km}$ sub-bottom of the lowermost slope. Moreover, on seismic line MX-16, the ocean crust reflector is recorded at a sub-bottom depth of 4 to $5 \mathrm{~km}$, below a zone lacking coherent reflectors (Fig. 6; Shipley, this volume). Clearly, seismic energy is traversing the zone of underplating, and thus the most likely explanation of the lack of coherent reflections from the underplated deposits is deformation more complex than that of the offscraped deposits. Any underplated material would have been underthrust a substantial distance before being transferred to the upper plate, with the potential for shear strain of large magnitude.

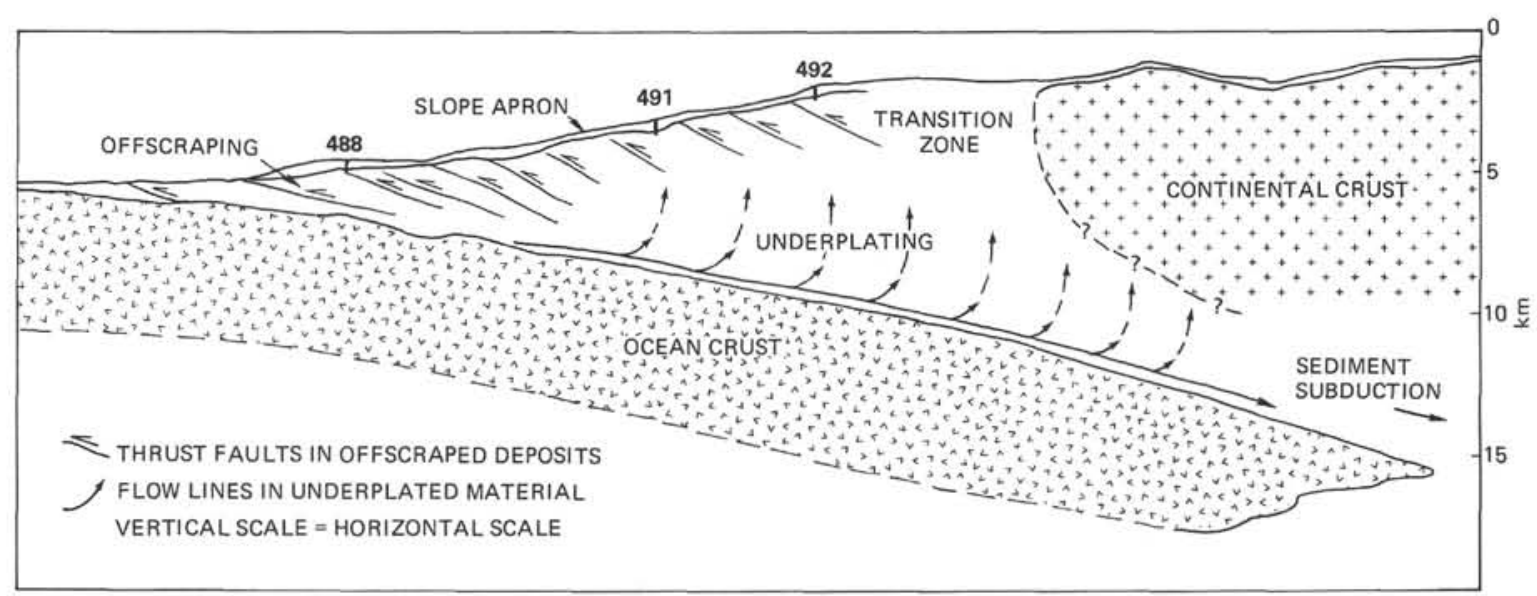

Figure 8. Composite structural cross section based on seismic line MX-16 and drilling results. Offscraped trench deposits constitute external rind of accretionary terrane beneath which underplating occurs. (Solid arrows in underplating zone describe particle flow for a short time interval. Dashed arrows represent long-term particle motion due to growth of the accretionary terrane over geologic time. Mass'balance calculations indicate sediment subduction [Watkins et al., this volume].) 
Pressure/temperature ranges of metamorphic facies based on experimental and stable isotope studies allow prediction of the degree of metamorphism developed in the offscraped and underplated terranes (Fig. 8; Ernst, 1974). Temperature is estimated from a measured thermal gradient of $2.2^{\circ} \mathrm{C} / 100 \mathrm{~m}$ over the zone of landward-dipping reflectors and $2.5^{\circ} \mathrm{C} / 100 \mathrm{~m}$ over the transition zone (Shipley and Shepard, this volume). Pressure determinations are based on an average density of 2.45 $\mathrm{gm} / \mathrm{cm}^{3}$ for the accreted rocks which is determined from an average sonic velocity of $3.5 \mathrm{~km} / \mathrm{s}$ (Watkins et al., this volume; Nafe and Drake, 1957). As such, the metamorphic grade of the offscraped deposits would range into zeolite facies with maximum burial of 3 to $4 \mathrm{~km}$ sub-bottom at $4 \mathrm{~km}$ water depth and a maximum temperature of about $80^{\circ} \mathrm{C}$. Metamorphism in the underplated material would initially be of zeolite facies but transitional to prehnite-pumpellite facies at depths greater than $10 \mathrm{~km}$ and temperatures exceeding $250^{\circ}$ where underplating occurs beneath the continental crust.

In summary, the underplated terrane probably would be composed of trench, hemipelagic, and pelagic deposits; this terrane will be more argillaceous than the offscraped trench deposits since it includes more ocean plate pelagic and hemipelagic material. In cases where the trench sediments coarsen upward (Piper et al., 1973; Moore and Karig, 1976) the upper coarser section might be offscraped, with the lower more argillaceous portion being underthrust to greater depths and underplated. Small pieces of ocean crust sheared off the downgoing plate might be included in the underplated terrane, although it is noteworthy that seismic reflection and refraction studies by Shipley et al. (1980) and Shipley (this volume) provide no evidence for large slabs of ocean crust in the accretionary terrane along the Leg 66 transect. The metamorphic grade of the offscraped terrane ranges to zeolite facies, whereas the underplated terrane includes rocks of zeolite and prehnite-pumpellite facies. Overall, the underplated terrane is probably more complexly deformed than the offscraped terrane by virtue of the greater depth of underthrusting of the former.

\section{Kinematics of Underplating}

The uplift landward of the zone of imbricate wedging must represent some type of mass transfer process from the downgoing plate to the accretionary terrane. The uplift rates could be explained by underthrusting a thin selvage of the offscraped sediment package to great depth, but the seismic data provide no evidence for this process. Indeed, underthrusting of such thin slices of weak sedimentary rock to great depths appears physically unlikely. Rather, we argue for a more diffuse process of mass transfer of ductile sediments from the downgoing plate.

Cowan and Silling (1978) and Cloos (in press) argue from experiments and theoretical considerations that the downgoing flow of deeply underthrust sediment is progressively diverted upward owing to the effects of a rigid buttress marking the landward boundary of the accretionary terrane. A modification of their model may be applied to the Leg 66 transect, with the continental crust representing a landward but in part overlying buttress. In the case of the Leg 66 transect the flow pattern is constrained by the consumption of a significant portion of the underthrust sediment and a low velocity of vertical motion as determined from the uplift rates (McMillen and Bachman, this volume).

The rate of underthrusting of the downgoing slab is about 300 to 600 times faster than the uplift of the trench slope landward of Site 488 (McMillen and Bachman, this volume). Thus for any given time interval the component of vertical motion due to underplated sediment is small compared to the velocity of the underthrust ocean crust and closely coupled sediment (Fig. 8). Since there appears to be no significant differential uplift between the landward portion of the accretionary zone and the continental crust (McMillen and Bachman, this volume), the component of return flow or movement relative to the continental basement is negligible (compare Cowan and Silling's figure 8 [1978] to Fig. 8 herein).

Although the solid arrows on Figure 8 depict underflow for a short time interval, the dashed arrows show upward flow of a longer duration with a component of landward motion resulting from the shear couple generated by the downgoing slab. The arrows represent the overall movement pattern in the underplating zone and are not meant to specify the geometry and/or displacements of smaller scale structures that accommodate flow.

The youth and limited extent of the accretionary zone and zone of underplating in the Leg 66 area may constrain the complexity of the flow pattern. More elaborate schemes, including return flow, may evolve only in a larger, more mature accretionary zone with deeper underthrusting than that depicted in Figure 8 (Cowan and Silling, 1978; Cloos, in press).

\section{Underplated Rocks in the Stratigraphic Record}

A comparison of the geologic characteristics of the accreted versus the underplated rocks indicates that the latter should be more deformed, more metamorphosed, and lithologically more heterogeneous than the former (Table 1). Hence these two types of tectonostratigraphic

Table 1. Characteristics of offscraped vs. underplated deposits, DSDP Leg 66.

\begin{tabular}{|c|c|c|}
\hline & Offscraped & Underplated \\
\hline Lithology & $\begin{array}{l}\text { Sand/sandstone } \\
\text { Hemipelagic mud } \\
\text { Mudstone }\end{array}$ & $\begin{array}{l}\text { Hemipelagic mud/mudstone } \\
\text { Sand/sandstone } \\
\text { Pelagic mud/mudstone(?) } \\
\text { Basalt(?) }\end{array}$ \\
\hline Structure & $\begin{array}{l}\text { Coherent bedding } \\
\text { Stratal disruption } \\
\text { Thrust faulting } \\
\text { Scaly clay }\end{array}$ & $\begin{array}{l}\text { Stratal disruption } \\
\text { Scaly clay } \\
\text { Thrust faulting(?) } \\
\text { Exotic blocks? }\end{array}$ \\
\hline Metamorphism & $\begin{array}{l}\text { Nil to } \\
\text { zeolite facies }\end{array}$ & $\begin{array}{l}\text { Zeolite facies to prehnite- } \\
\text { pumpellite }\end{array}$ \\
\hline $\begin{array}{l}\text { Possible onland } \\
\text { equivalents }\end{array}$ & $\begin{array}{l}\text { Broken } \\
\text { formation }\end{array}$ & Melange(?) \\
\hline
\end{tabular}


units should be distinguishable in ancient subduction complexes.

Mesozoic and Paleogene subduction complexes in California (Blake and Jones, 1974; Ernst, 1975), Southeastern Alaska (Decker, 1980), and the Kodiak Islands (Moore and Connelly, 1979) generally decrease in degree of metamorphism, deformation, and lithologic heterogeneity in a seaward direction. In part these trends may reflect transition from underplated to accreted terranes, although in most instances the contrasting terranes are of differing ages and their variation could be explained by secular changes in the type of underthrust sediment, convergence velocity, or other parameters.

The most probable case for a transition from underplated to accreted rocks can be made in the Kodiak Islands, since the contrasting terranes are nearly of the same age. Here the Uyak melange, which is lithologically heterogeneous, structurally complex, and of prehnite-pumpellite facies metamorphism (Connelly, 1978), occurs landward of less-deformed and less-metamorphosed turbidite sequence, the Kodiak Formation, that accumulated in the trench and/or trench slope environment (Nilsen and Moore, 1979). Both of these rock units were emplaced in the Late Cretaceous, possibly simultaneously or (more likely) sequentially over a short time interval (Moore, 1978). The Uyak melange contains blocks of massive sandstone, bedded chert, and ocean crustal lithologies in a matrix of gray chert and argillite or probable hemipelagic origin (Connelly, 1978). Clearly, mixing of oceanic and continental-margin lithologies occurs in the Uyak melange which would be expected in the underplating environment. In contrast, the Kodiak Formation consists only of sandstone and argillaceous rocks with virtually no materials of pelagic or ocean crust origin (Nilsen and Moore, 1979).

\section{PROPAGATION OF DEFORMATION THROUGH ACCRETIONARY ZONE INTO SLOPE APRON}

The seismic reflection data (Figs. 4-6; Shipley, this volume) substantiate significant deformation of the trench sediments at the toe of the trench slope. Moreover, structural study of the drill holes indicates propagation of deformation through the overlying slope apron. Clearly, the slope deposits are being tectonically incorporated or "kneaded" (Scholl et al., 1980) into the accretionary zone. Of crucial interest is the rate at which this process operates. Although the cores from Leg 66 recovered no material useful for finite strain determinations, the incremental steepening of bedding dips provides a crude measure of magnitude and hence of rate of deformation.

Using the structural data of Lundberg and Moore (this volume), we have plotted the ages at which dips consistently greater than $25^{\circ}$ occur downhole at Sites 488 and 490-493 (Fig. 9). We define bedding inclinations of $25^{\circ}$ or greater from the horizontal as a "significant degree of deformation" or essentially a qualitative unit of strain. Since seismic line MX-16 (Shipley, this volume) shows reflectors(bedding) inclined about $25^{\circ}$ in folded trench sediments less than 100,000 years old, this measure of significant deformation is compared to the data from the drill holes (Fig. 9). To establish the deformation rate, the age of the first occurrence of significant deformation has been inverted and plotted also on Figure 9. The downhole transition to the threshold of significant deformation is gradual, suggesting that the deformation process is continuous. It is notable that at Sites 488, 491, and 492 the threshold of significant deformation was reached in the slope apron above the zone of landward-dipping reflectors.

The age of the threshold of significant deformation increases systematically from the base of the trench slope to Site 492, landward of which it decreases somewhat to remain constant through Sites 490 and 493 . Representing this information in inverted form, we recognize a dramatic drop in the rate of deformation from the base of the slope through Site 491, with less significant fluctuations in deformation rate landward. Since the depth to ocean crust is known landward to Site 491 and can be estimated at Site 492 , we have plotted this parameter against deformation rate (Fig. 10). Expectably the deformation rate decreases very rapidly and systematically with distance above the ocean crust, closely approximating a power function (Fig. 10).

Intepretation of the foregoing deformation rate data is hindered by its unorthodox nature and by the small number of measurements. Nevertheless it represents provide the only even semiquantitative information of this kind. As the rate of deformation across the trench decreases from its base, so would the tectonic kneading of slope deposits into the underlying offscraped rocks. Hence slope sediments accumulated landward of the lowermost slope (above about $3.4 \mathrm{~km}$ water depth) would be more likely to be structurally differentiable from underlying structurally accreted rocks than those deposited in deeper water, closer to the base to the trench slope. In part, the structural data from Leg 66 support this generality, as stratal disruption similar to that in the zone of dipping reflectors occurs only in rocks accumulated on the lowermost slope (Lundberg and Moore, this volume).

The systematic drop in deformation rate from the base of the trench slope to Site 492 might be related to decreasing proximity from a shear zone between the ocean crust and the accretionary zone. Alternatively, the deformation might be due to creep or slumping of the slope apron (see Lundberg and Moore, this volume). As such, the change in deformation could reflect a landward reduction in tectonic disturbance and sedimentation rate (Shepard and McMillen, this volume) and therefore less tendency for down-slope movements.

\section{CONCLUDING REMARKS}

Of the material discussed in this chapter three points are especially significant for the interpretation of ancient subduction complexes: (1) Trench deposits can be progressively scraped off the downgoing plate to constitute successive thrust-bound packages that decrease in age seaward; (2) a separate, deeper-level accretionary process or underplating is required to explain the total uplift of the offscraped trench deposits in the absence of their continued landward tilting; and (3) slope deposits 


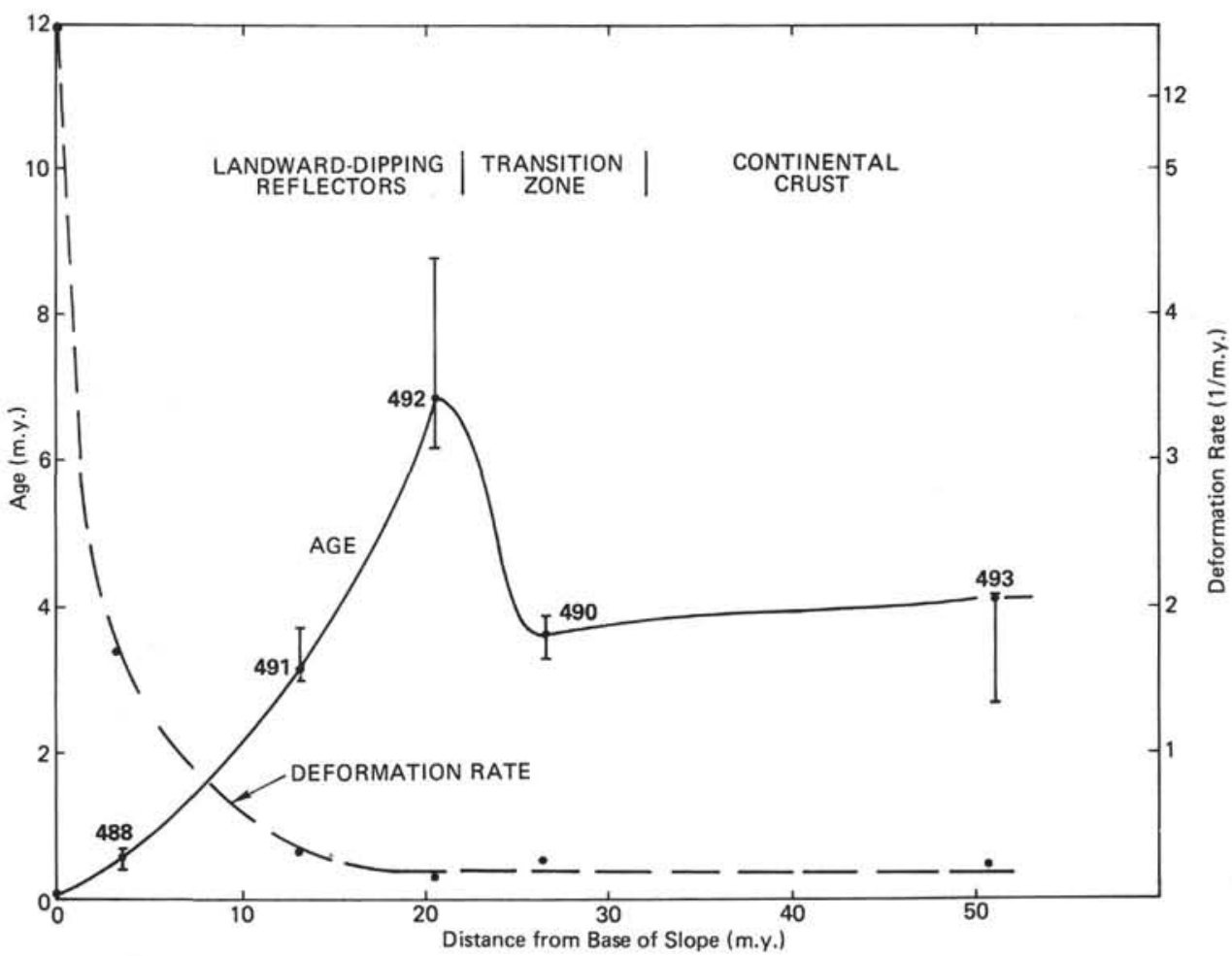

Figure 9. Age of significant deformation (left vertical scale) and deformation rate (right vertical scale) versus distance from base of trench slope. Significant deformation defined by first downhole occurrence of consistent bedding tilts of $25^{\circ}$ or greater at Sites 488,491 , and 492 . A tilt of about $25^{\circ}$ in deformed trench sediments used to define significant deformation at base of slope. Deformation rate represents reciprocal of age of significant deformation.

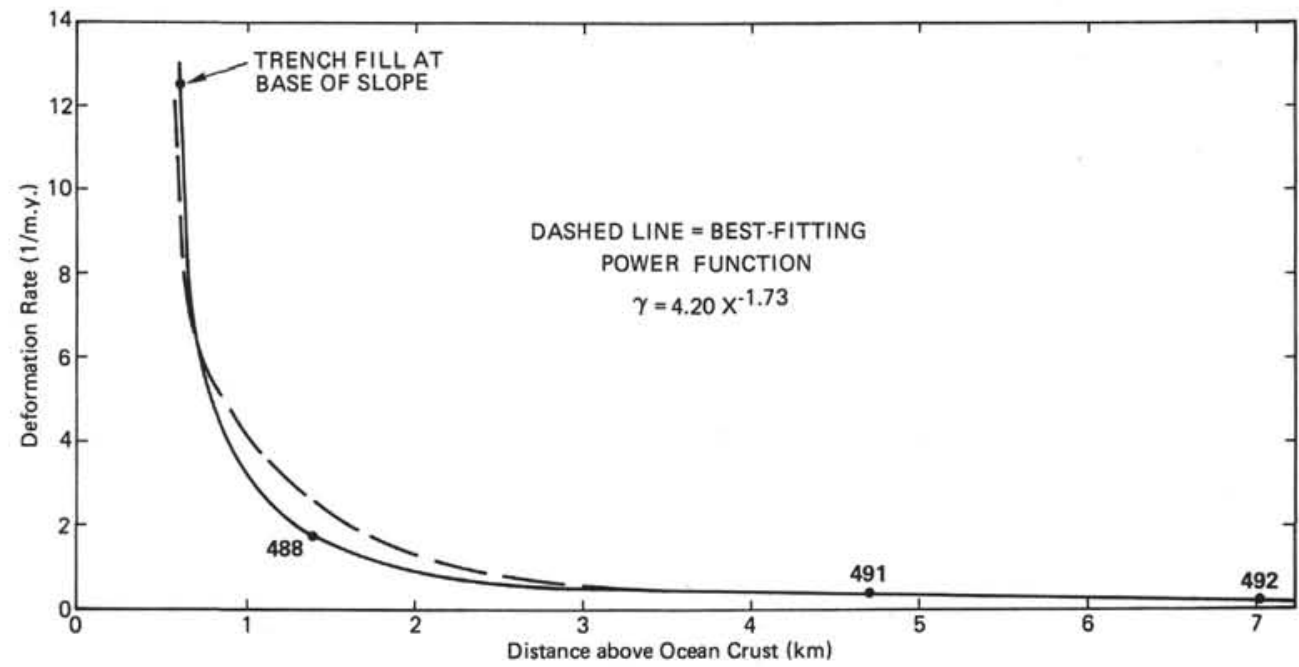

Figure 10. Deformation rate (defined as in Fig. 9) versus distance above ocean crust of downgoing slab. Depth to ocean crust beneath Site 492 extrapolated from dip of downgoing slab. (Dashed line represents best-fitting power function.)

undergo progressive deformation and can become structurally indistinguishable from the underlying accretionary terrane.

The distinction between offscraping and underplating provides new possibilities for the interpretation of ancient accretionary terranes. The criteria for separation of offscraped and underplated deposits (Table 1) are based solely on the Leg 66 transect but seem to ac- count for two contrasting tectonic units in the Kodiak Islands, Alaska. Although it may be presumptuous to equate the offscraped and underplated terranes to broken formations and melanges, respectively, lithologic and structural parallels do exist. Our drilling and seismic data indicate that the offscraped terrane is both coherent and disrupted, and lithologically monotonous-not unlike a broken formation. Conversely, the 
underplated terrane appears to be both structurally complex and lithologically diverse and may resemble melange. Of course, the chaotic seismic returns of the underplated terrane may be generated in sequences whose deformation is less intense than that producing stratal disruption, an essential characteristic of melanges.

\section{ACKNOWLEDGMENTS}

We acknowledge the National Science Foundation and similar agencies in France, Great Britain, Japan, West Germany, and the U.S.S.R. for support of the International Program of Ocean Drilling. The marine crew, drilling crew, and technical staff of the Glomar Challenger were exceptionally cooperative in the collection and shipboard examination of the cores on Leg 66. We thank Eli Silver and Mark Cloos for reviews of the manuscript. Bruce Jaffee constructed the depth sections in Figures 4-7. Acknowledgment is also made to the donors of the Petroleum Research Fund, administered through the American Chemical Society, for partial support of this research through Grant PRF 9219-AC2.

\section{REFERENCES}

Blake, M. C., Jr., and Jones, D. L., 1974. Origin of Franciscan melange in Northern California. Spec. Publ. Soc. Econ. Paleontol. Mineral, 19:345-357.

Byrne, T., in press. Structural geology of coherent terranes, Ghost Rocks Formation, Kodiak Islands, Alaska. In Leggett, J. K. (Ed.), Trench and Forearc Sedimentation and Tectonics: London (Spec. Publ. Geol. Soc. London).

Cantagrel, J. H., and Robin, C., 1979. K-Ar dating on eastern Mexican volcanic rocks-relations between andesitic and alkaline provinces. J. volcanol. Geotherm. Res., 5:99-114.

Carson, B., Yuan, J., Myers, P. B., Jr., et al., 1974. Initial deep-sea sediment deformation at the base of the Washington continental slope: A response to subduction. Geology, 2:561-564.

Cloos, M., in press. Flow melanges: Numerical modeling and structural and metamorphic constraints on their origin in the Franciscan subduction complex, California. Geol. Soc. Am. Bull.

Connelly, W., 1978. Uyak complex, Kodiak Islands, Alaska: A Cretaceous subduction complex. Geol. Soc. Am. Bull., 89:755-769.

Cowan, D. S., 1978. Origin of blueschist-bearing chaotic rocks in the Franciscan Complex, San Simeon, California. Geol. Soc. Am. Bull., 89:1419-1423.

Cowan, D. S., and Silling, R. M., 1978. A dynamic, scaled model of accretion at trenches and its implications for the tectonic evolution of subduction complexes. J. Geophys. Res., 83:5389-5396.

Decker, J., 1980. Geologic map of western Chicagof Island, southeastern Alaska. Geol. Surv. Open File Rep., 80-150.

Duffield, W. A., and Sharp, R. V., 1975. Geology of the Sierra foothills melange and adjacent areas, Amador County, California. U.S. Geol. Surv. Prof. Pap., 827.

Ernst, W. G., 1974. Metamorphism and ancient continental margins. In Burk, C. A., and Drake, C. L. (Eds.), The Geology of Continental Margins: New York (Springer-Verlag), pp. 907-919. , 1975. Systematics of large-scale tectonics and age progression in Alpine and Circumpacific blueschist belts. Tectonophysics, 26:229-246.

Karig, D. E., 1974. Evolution of arc systems in the western Pacific. Ann. Rev. Earth Planet. Sci., 2:51-76.

Karig, D. E., Cardwell, R. K., Moore, G. F., et al., 1978. Late Cenozoic subduction and continental margin truncation along the northern Middle America Trench. Geol. Soc. Am. Bull., 89:265276.

Karig, D. E., Moore, G. F., Curray, J. R., et al., 1980. Morphology and shallow structure of the lower trench slope off Nias Island, Sunda Arc. Am. Geophys. Union, Geophysical Monograph 23: 179-208.
Mejorada, S. H. S., 1976. Carta Geologica de la Republica Mexicana (4th ed.): Mexico (Instituto de Geologia, U.N.A.M. Ciudad Universitaria).

Minster, J. B., and Jordan, T. H., 1978. Present-day plate motions. J. Geophys. Res., 83:5331-5354.

Moore, G. F., and Karig, D. E., 1980. Structural geology of Nias, Implications for subduction zone tectonics. Am. J. Sci., 280: 193-223.

Moore, J. C., 1978. Orientation of underthrusting during latest Cretaceous and earliest Tertiary time, Kodiak Islands, Alaska. Geology, 6:209-213.

Moore, J. C., and Connelly, W., 1979. Tectonic history of the continental margin of southwestern Alaska. Late Triassic to earliest Tertiary. In Sisson, A. (Ed.), The Relationship of Plate Tectonics to Alaskan Geology and Resources, H1-H29: Anchorage (Alaska Geological Society).

Moore, J. C., and Karig, D. E., 1976. Sedimentology, structural geology, and tectonics of the Shikoku subduction zone, southwest Japan. Geol. Soc. Am. Bull., 87:1259-1268.

Moore, J. C., Watkins, J. S., Shipley, T. H., et al., 1979. Progressive accretion in the Middle America Trench, Southern Mexico. Nature, 281:638-642.

Moore, J. C., and Wheeler, R. L., 1978. Structural fabric of a melange, Kodiak Islands, Alaska. Am. J. Sci., 278:739-765.

Nafe, J. E., and Drake, C. L., 1957. Variations with depth in shallow and deep water marine sediments of porosity, density and the velocities of compressional waves. Geophysics, 22:523-552.

Nilsen, T. H., and Moore, G. W., 1979. Reconnaissance of Upper Cretaceous to Miocene stratigraphic units and sedimentary facies, Kodiak and adjacent islands, Alaska. U.S. Geol. Surv. Prof. Pap., 1093.

Page, B. M., 1981. Southern coast ranges. In Ernst, W. G. (Ed.), Geotectonic Development of California: New York (Prentice-Hall).

Piper, D. J. W., von Huene, R., and Duncan, J. R., 1973. Late Quaternary sedimentation in the active eastern Aleutian Trench. Geology, 1:19-26.

Renard, V., Aubouin, J., Lonsdale, P., et al., 1980. First results of a seabeam survey in the Mid-America Trench. C.R. Hebd. Seances Acad. Sci., 291, Ser. D:137-142. (In French)

Scholl, D. W., von Huene, R., Vallier, T. L., et al., 1981. Sedimentary masses and concepts about tectonic processes at underthrust ocean margins. Geology, 8:564-568.

Seely, D. R., 1977. The significance of landward vergence and oblique structural trends on trench inner slopes. In Talwani, M., and Pitman, W. C. III (Eds.), Island Arcs, Deep Sea Trenches, and BackArc Basins: Washington (Maurice Ewing Series 1, American Geophysical Union), pp. 187-198.

Seely, D. R., Vail, P. R., and Walton, G. G., 1974. Trench slope model. In Burke, C. A., and Drake, C. L. (Eds.), The Geology of Continental Margin: New York (Springer-Verlag), pp. 249-260.

Shipley, T. H., McMillen, K. J., Watkins, J. S., et al., 1980. Continental margin of Guerrero and Oaxaca, Mexico. Mar. Geol., 35:65-82.

Silver, E. A., 1972. Pleistocene tectonic accretion of the continental slope off Washington. Mar. Geol., 13:239-249.

Suppe, J. 1973. Geology of the Leech Lake Mountain-Ball Mountain range, California. Univ. Calif. Berkeley Publ. Geol. Sci., 107.

von Huene, R., Aubouin, J., et al., 1980. Leg 67 the DSDP MidAmerica Transect off Guatemala. Geol. Soc. Am. Bull., 91: 421-432.

von Huene, R., Moore, G. W., and Moore, J. C., 1979. Cross section, Alaska Peninsula, Kodiak Island, Aleutian Trench. Map Chart Ser. Geol. Soc. Am., MC284.

Watkins, J. S., Moore, J. C., Shipley, T. H., et al., in press. Accretion, underplating, subduction and tectonic evolution, Middle America Trench, southern Mexico: Results from Leg 66 DSDP. Oceania Acta.

Westbrook, G. K., 1975. The structure of the crust and upper mantle in the region of Barbados and the Lesser Antilles. R. Astron. Soc. Geophys. J., 43:1-42. 